\title{
Influence of Telfairia mosaic virus on Growth, Yield and Phytonutrients of Amaranthus viridis L.
}

\section{Mofunanya AAJ ${ }^{1 *}$, Ogar V B ${ }^{1}$, Udosen I $\mathrm{R}^{2}$ and Owolabi A T ${ }^{3}$}

${ }^{1}$ Department of Botany, Faculty of Biological Sciences, University of Calabar, Nigeria

${ }^{2}$ Department of Biology, College of Education, Afaha Nsit, Akwa Ibom State, Nigeria

${ }^{3}$ Department of Botany, Faculty of Biological Sciences, University of Calabar,

Nigeria

*Corresponding Author: Mofunanya AAJ, Department of Botany, Faculty of

Biological Sciences, University of Calabar, Nigeria.
Received: February 23, 2021

Published: March 06, 2021

(C) All rights are reserved by Mofunanya AAJ., et al.

\begin{abstract}
Amaranthus viridis is a vegetable crop of the Nigerian people with great economic and medicinal potentials. A study was conducted to investigate effect of Telfairia mosaic virus on growth, yield and phytonutrients of Amaranthus viridis. Seeds of $A$. viridis were obtained, sown and on germination inoculated with TeMV, effect on growth and yield assessed at 2, 4, 6, 8, and 12 weeks after inoculation (WAI), minerals and vitamins analyzed at 8 WAI. Results revealed that TeMV decreased growth and yield of A. viridis by $58.8 \%$ (leaf area), shoot height (59.0\%), number of primary shoot (51.5\%), number of leaves produced (60.5\%), leaf fresh weight $(65.7 \%)$ and leaf dry weight (54.9\%) at 12 WAI. Decrease in shoot fresh weight was 30.2\%, root dry weight (22.4\%). At 4 WAI, relative growth rate suffered reduction of $33.3 \%$, net assimilation rate $40.2 \%$ while leaf area ratio had a decrease of $42.1 \%$ at 12 WAI. The virus caused reduction in copper, phosphorus, magnesium, calcium, iron, zinc and sodium, effect on potassium, and manganese was not significant. Decrease in leaf $\mathrm{Cu}$ was $91.0 \%$, stem (90.5\%) and root (90.1\%). The virus engendered drastic reduction in thiamine, pyridoxine, $\beta$-carotene, ascorbic acid, niacin, pantothenic acid, folate, $\alpha$-tocopherol and riboflavin. Thiamine had reduction of $62.0 \%$ (leaf), $52.0 \%$ (stem), and $40.7 \%$ (root). The presence of medicinal nutrients in all plant parts affirmed A. viridis whole plant usage in traditional medical practice. Reduction in economic and medicinal potentials confirmed negative impact of TeMV on $A$. viridis necessitating its control.
\end{abstract}

Keywords: Amaranthus viridis; Growth; Phytonutrients Nutrients; Telfairia Mosaic Virus; Yield

\section{Introduction}

Amaranthus viridis L. (Amaranthaceae) is an annual herbaceous plant with an erect stem. It is eaten traditionally as a vegetable in Nigeria, and other parts of Africa [1]. In Nigeria, leafy vegetables are traditionally cooked and eaten as relish with starchy staple food. Amaranthus viridis contain large amount of nutrients: pro- tein, ash, fibre, fat, carbohydrate, amino acids, minerals, vitamins and antinutrients with known health and industrial benefits [2]. Because of its rich phytonutrients, $A$. viridis is used in traditional medical practice as an anti-inflammatory agent of the urinary tract; the root juice is used to treat inflammation during urination and constipation [3], in venereal diseases, as an emollient and vermi- 
fuge [4], diuretic, antirheumatic, antiulcer, analgesic, antiemetic, laxative, for improving appetite, as an antileprotic, for the treatment of respiratory problems, eye treatment and for asthma [5], analgesic and antipyretic [6]. A decoction of the entire plant is used to stop dysentery and inflammation [7]. A novel antiproliferative and antifungal lactin and a ribosome inactivating protein, $\beta$-carotene was isolated from $A$. viridis [8]. In traditional medicine, the whole plant of $A$. viridis is useful in the treatment of pain and fever.

Plants react when subjected to virus stress by the production of several reactive oxygen species (ROS) which causes damaging effects on host plant cells. The host-virus interaction suggests a highly complex network of plant responses and the viral counterresponses which greatly impact the physiology of the plant [9]. Amaranthus viridis is a vegetable of high economic and medicinal value. However, the production of $A$. viridis is severely limited by virus diseases with significant yield losses. Amaranthaceae family was reported as one of the susceptible hosts to Telfairia mosaic virus [10]. Despite our knowledge on effect of other viruses on this vegetable, no literature is found on the impact of Telfairia mosaic virus on A. viridis. [11] had focused on the effect of TeMV on enzymes activities of $A$. viridis. The present study was designed to assess the damage posed by Telfairia mosaic virus stress on the growth, yield and phytonutrients of Amaranthus viridis with the view to advance research on TeMV control to maximize the worth of this important vegetable.

\section{Materials and Methods}

\section{Planting materials inoculation}

Inflorescence of $A$. viridis from which seeds were obtained was purchased from a farmer at Akparabong, Ikom Local Government Area of Cross River State, Nigeria whose plants were monitored on the field for symptoms expression. The seeds were raised in nursery before transplanting to the Botanical Garden of Department of Botany greenhouse, University of Calabar, Nigeria. The seeds spouted eight days after planting (DAP) and the seedlings inoculated at two-leaf stage. Telfairia mosaic virus isolate obtained from the Federal Biological Research Centre for Agriculture and Forestry Braunschweig, Germany was reactivated by homogenizing the leaf tissue in a sterile laboratory mortar and pestle in cold disodium phosphate buffer $0.03 \mathrm{M}, \mathrm{pH}$ 8.0. The inoculum prepared was applied mechanically on $A$. viridis leaves pre-dusted with car- borundum (800-mesh), inoculated leaves rinsed with water and observed for symptom development (8-10 days) such as mosaic, severe leaf malformation and distortion characteristics of TeMV infection under greenhouse condition of $25 \pm 3^{\circ} \mathrm{C}$. A total of 60 plants were used, thirty for inoculated and thirty for control.

Influence of Telfairia mosaic virus on plant growth and yield parameters

Effect of Telfairia mosaic virus on the growth of $A$. viridis after transplantation was determined at various periods of growth. For agromorphological parameters; Leaf area, shoot height, number of primary shoot branches and number of leaves produced were determined. Leaf area estimation was carried out by measuring the leaf length (L) in centimeters along the leaf midrib, from the base to apex without the petiole; and leaf width (W) in centimeters was measured perpendicular to the midrib from one end of the leaf to the other. The readings obtained were then used to estimate the leaf area by applying [12] equation.

AfLW $=-27.7418+(3.9812 \mathrm{LW} / \mathrm{In} \mathrm{LW})$

Where, $\mathrm{L}$ is the leaf length and $\mathrm{W}$ is the width.

Shoot height of $A$. viridis was measured in centimeters from the base to the tip of the plant, number of leaves produced, number of primary shoot were counted for healthy and virus infected plants at various stages of growth. Leaf fresh weight, leaf dry weight, fresh weight of shoot and root, dry weight of shoot and root at the end of experiment (13 WAI) were estimated by weighing. Leaves were harvested per plant, fresh weight taken before drying to constant weight at a temperature of $60^{\circ} \mathrm{C}$ in Hot Box Oven Gallenkamp, CHF097 XX2.5, England), shoot and root at $74^{\circ} \mathrm{C}$ for $24 \mathrm{~h}$. Relative growth rate, net assimilation rate and leaf area ratio of inoculated and control plants of $A$. viridis were determined according to [13].

\section{Sample analysis}

At $8 \mathrm{WAI}$, leaf, stem and root parts of the vegetable were collected, dried, pulverized and used to analyze the presence of minerals and vitamins in A. viridis. Mineral nutrients ( $\mathrm{Ca}, \mathrm{Fe}, \mathrm{Mg}, \mathrm{Zn}, \mathrm{Cu}$ and P) of inoculated and control samples were determined using atomic absorption spectrophotometer (Pye Unicam SP8-190, Spec. UK) as outlined in [14]. Sodium and K were estimated by flame photometry (Jahway Flame Analyzer P. F7, UK). Vitamin A ( $\beta$-carotene) content was determined spectrophotometrically using the hexane 
Influence of Telfairia mosaic virus on Growth, Yield and Phytonutrients of Amaranthus viridis L.

method. Vitamin C (ascorbic acid), $\mathrm{B}_{1}$ (Thiamine), $\mathrm{B}_{2}$ (riboflavin), $\mathrm{B}_{3}$ (niacin), $\mathrm{B}_{5}$ (pantothenic acid), $\mathrm{B}_{6}$ (pyridoxine), $\mathrm{B}_{9}$ (folate) were analyzed by [15].

\section{Statistical analysis}

The data obtained in this study were analyzed using the independent $t$-Test to determine significant differences between means of inoculated and control plants. Results were also expressed as percentage difference and differences between mean values were determined at $5 \%$ probability.

\section{Results}

The growth of $A$. viridis was severely affected by TeMV. Under condition of virus infection, the leaf area, shoot height, number of primary shoot and number of leaves produced per plant for inoculated plant significantly $(\mathrm{P}=0.05)$ decreased compared to control plant. At 2 WAI the virus did not produce any statistical effect on all growth components studied. Effect however, became significant with prolonged infection. Growth parameters for virus inoculated plant at 12 WAI had mean decrease of $32.78 \pm 0.01 \mathrm{~cm}^{2}$ (leaf area), $25.48 \pm 0.01 \mathrm{~cm}$ (shoot height), $3.11 \pm 0.01$ (number of primary shoot) and $25.19 \pm 0.01$ (number of leaves produced) respectively compared to control values of $79.55 \pm 0.01 \mathrm{~cm}^{2}, 61.50 \pm 0.01 \mathrm{~cm}$, $6.32 \pm 0.01$ and $63.8 \pm 0.01$ at 12 WAI respectively (Table 1 ).

The virus had a negative effect on yield with significant $(\mathrm{P}=$ 0.05 ) reduction on LFW and LDW of $A$. viridis. No reduction occurred on LFW $(2.08 \pm 0.02 \mathrm{~g})$ and $\operatorname{LDW}(2.08 \pm 0.02 \mathrm{~g})$ at $2 \mathrm{WAI}$

\begin{tabular}{|c|c|c|c|c|c|c|c|c|}
\hline \multirow{2}{*}{ WAI } & \multicolumn{2}{|c|}{ Leaf area $\left(\mathrm{cm}^{2}\right)$} & \multicolumn{2}{|c|}{ Shoot height (cm) } & \multicolumn{2}{|c|}{ Number of primary shoot } & \multicolumn{2}{|c|}{ Number of leaves produced } \\
\hline & Control & Inoculated & Control & Inoculated & Control & Inoculated & Control & Inoculated \\
\hline 2 & $5.10 \pm 0.02$ & $5.10 \pm 0.01$ & $5.86 \pm 0.01$ & $5.85 \pm 0.00$ & $0.00 \pm 0.00$ & $0.00 \pm 0.00$ & 0.01 & $2.14 \pm 0.01$ \\
\hline 4 & $16.39 \pm 0.01$ & $11.32 \pm 0.02^{*}$ & $15.23 \pm 0.03$ & $10.06 \pm 0.02 *$ & $4.65 \pm 0.01$ & $0.03^{*}$ & 0.01 & $0.03^{*}$ \\
\hline 8 & $64.43 \pm 0.02$ & $28.85 \pm 0.01 *$ & $52.49 \pm 0.03$ & $18.27 \pm 0.01 *$ & $5.58 \pm 0.00$ & $2.27 \pm 0.01^{*}$ & $46.91 \pm 0.01$ & $13.48 \pm 0.02^{*}$ \\
\hline 12 & $92.15 \pm 0.01$ & $39.78 \pm 0.03 *$ & $63.50 \pm 0.01$ & $25.68 \pm 0.01^{*}$ & $7.32 \pm 0.01$ & $3.41 \pm 0.01^{*}$ & $70.8 \pm 0.01$ & $29.19 \pm 0.01^{*}$ \\
\hline
\end{tabular}

Table 1: Influence of Telfairia mosaic virus on growth parameters per plant of Amaranthus viridis.

Values are Mean $\pm \mathrm{SD}, \mathrm{n}=3, \mathrm{P}=0.05,^{*}=$ significant.

when virus infected and control plants were compared. Leaf fresh weight had mean reduction for inoculated plant at 2 and 12 WAI of $2.08 \pm 0.02 \mathrm{~g}$ and $29.91 \pm 0.01 \mathrm{~g}$ compared to control plant of $2.08 \pm$ $0.02 \mathrm{~g}$ and $81.29 \pm 0.01 \mathrm{~g}$. Corresponding reductions for LDW were $0.05 \pm 8.5 \mathrm{E}-18$ and $7.11 \pm 0.01 \mathrm{~g}$ for inoculated plant in comparison to control plant of $0.05 \pm 8.5 \mathrm{E}-18$ and $15.75 \pm 0.01 \mathrm{~g}$ (Table 2).

Effect on RGR, NAR and LAR of $A$. viridis by Telfairia mosaic virus revealed drastic reductions. Impact on RGR and NAR had mean reduction per plant of $0.0058 \pm 1 \mathrm{E}-04$ gg $^{-1} \mathrm{day}^{-1}, 0.00070 \pm$ $0.00001 \mathrm{~g} \mathrm{~cm}^{-2}$ day $^{-1}$ for inoculated plant and $0.0087 \pm 1 \mathrm{E}-04 \mathrm{gg}^{-}$ ${ }^{1}$ day $^{-1}, 0.000117 \pm 0.001 \mathrm{~g} \mathrm{~cm}^{-2}$ day $^{-1}$ for control plant at 4 WAI. Corresponding effect on LAR depicted reduction per plant of $9.85 \pm$ 0.01 and $17.01 \pm 0.02 \mathrm{~cm}^{-2} \mathrm{~g}^{-1}$ for inoculated and control plants at 12 WAI. Results showed a trend of decrease in RGR and NAR with prolonged period of growth, while LAR had a trend of increase

\begin{tabular}{|l|c|c|c|c|}
\hline \multirow{2}{*}{ WAI } & \multicolumn{2}{|c|}{ Leaf fresh weight (LFW) } & \multicolumn{2}{c|}{ Leaf dry weight (LDW) } \\
\cline { 2 - 5 } & Control & Inoculated & Control & Inoculated \\
\hline 2 & $2.08 \pm 0.02$ & $2.08 \pm 0.01$ & $0.05 \pm 8.5 \mathrm{E}-18$ & $0.05 \pm 8.5 \mathrm{E}-18$ \\
\hline 4 & $17.17 \pm 0.011$ & $8.33 \pm 0.01^{*}$ & $2.08 \pm 0.01$ & $2.04 \pm 0.02$ \\
\hline 8 & $73.16 \pm 0.01$ & $25.09 \pm 0.0^{*}$ & $11.28 \pm 0.01$ & $6.25 \pm 0.01^{*}$ \\
\hline 12 & $81.29 \pm 0.01$ & $29.91 \pm 0.01^{*}$ & $15.75 \pm 0.01$ & $7.11 \pm 0.01^{*}$ \\
\hline
\end{tabular}

Table 2: Influence of Telfairia mosaic virus on leaf fresh and dry weight per plant of Amaranthus viridis.

Means of three replicates $\pm \mathrm{SD}, \mathrm{P}=0.05, *$ significant

with progressive period of growth for both inoculated and control plants (Table 3).

At the end of the study (13 WAI), the shoot and root were harvested, weighed and analyzed. Results revealed that the virus 
Influence of Telfairia mosaic virus on Growth, Yield and Phytonutrients of Amaranthus viridis L.

\begin{tabular}{|l|c|c|c|c|c|c|}
\hline \multirow{2}{*}{ WAI } & \multicolumn{2}{|c|}{$\begin{array}{c}\text { RGR }\left(\mathrm{gg}^{-1} \mathrm{day}^{-1}\right) \\
\text { Control Inoculated }\end{array}$} & \multicolumn{2}{c|}{$\begin{array}{c}\text { NAR }\left(\mathrm{g} \mathrm{cm}^{-2} \mathbf{~ d a y}^{-1}\right) \\
\text { Control Inoculated }\end{array}$} & \multicolumn{3}{c|}{$\begin{array}{c}\text { LAR }\left(\mathrm{cm}^{-2} \mathbf{g}^{-1}\right) \\
\text { Control Inoculated }\end{array}$} \\
\hline 4 & $0.0087 \pm 1 \mathrm{E}-04$ & $0.0058 \pm 1 \mathrm{E}-04^{*}$ & $0.000117 \pm 0.001$ & $0.00070 \pm 0.00001^{*}$ & $5.5 \pm 0.02$ & $4.06 \pm 0.03^{*}$ \\
\hline 8 & $0.0061 \pm 0.0002$ & $0.0045 \pm 1 \mathrm{E}-03^{*}$ & $0.00088 \pm 1 \mathrm{E}-05$ & $0.00062 \pm 0.0001^{*}$ & $9.95 \pm 0.01$ & $6.37 \pm 0.03^{*}$ \\
\hline 12 & $0.0035 \pm 0.0001$ & $0.0029 \pm 0.0001^{*}$ & $0.00060 \pm 1 \mathrm{E}-05$ & $0.00046 \pm 0.00001^{*}$ & $17.01 \pm 0.02$ & $9.85 \pm 0.01^{*}$ \\
\hline
\end{tabular}

Table 3: Influence of Telfairia mosaic virus on relative growth rate, net assimilation rate and leaf area ratio on per plant of Amaranthus viridis.

Means of three replicates $\pm \mathrm{SD}, \mathrm{P}=0.05, *$ significant.

caused significant $(\mathrm{P}=0.05)$ decrease with mean decrease in shoot fresh weight (SFW) per plant of $30.15 \pm 0.01 \mathrm{~g}$ as against control plant of $43.21 \pm 0.01 \mathrm{~g}$. Root dry weight (RDW) for inoculated plant had mean decrease of $1.85 \pm 0.01 \mathrm{~g}$ compared to control plant decrease of $2.19 \pm 0.01$ g. Shoot FW (30.2\%) and root DW (28.6\%) were significantly $(\mathrm{P}=0.05)$ decreased by TeMV infection while decrease in SDW and RFW was insignificant (Table 4).

\begin{tabular}{|l|l|c|c|c|c|}
\hline \multirow{3}{*}{ WAI } & \multirow{2}{*}{ Plant } & \multicolumn{2}{|c|}{ Shoot (g) } & \multicolumn{2}{c|}{ Root (g) } \\
\cline { 3 - 6 } & & Fresh weight & $\begin{array}{c}\text { Dry } \\
\text { weight }\end{array}$ & $\begin{array}{c}\text { Fresh } \\
\text { weight }\end{array}$ & $\begin{array}{c}\text { Dry } \\
\text { weight }\end{array}$ \\
\hline \multirow{2}{*}{13} & \multirow{2}{*}{ Control } & $43.21 \pm 0.01$ & $12.07 \pm$ & $17.63 \pm$ & $2.59 \pm$ \\
& & 0.11 & 1.73 & 0.01 \\
\hline \multirow{3}{*}{} & \multirow{2}{*}{ Inoculated } & $30.15 \pm 0.01 *$ & $11.38 \pm$ & $15.59 \pm$ & $1.01 \pm$ \\
& & & $0.02^{*}$ & 0.01 & $0.01^{*}$ \\
\hline
\end{tabular}

Table 4: Influence of Telfairia mosaic virus on fresh weight and dry weight of shoot and root per plant of Amaranthus viridis. Means of three replicates $\pm \mathrm{SD}, \mathrm{P}=0.05,^{*}=$ significant.

Results of effect on mineral nutrients as presented in table 5 revealed that TeMV caused drastic reduction in $\mathrm{Cu}, \mathrm{P}, \mathrm{Mg}, \mathrm{Ca}, \mathrm{Fe}, \mathrm{Zn}$ with insignificant reduction in $\mathrm{K}$ and $\mathrm{Mn}$. Severe reduction endangered by the virus on $\mathrm{Cu}$ and $\mathrm{Mg}$ had mean values of $0.099 \pm 0.06$, $0.097 \pm 0.06$ and $0.095 \pm 0.0 .3 \mathrm{mg} / 100 \mathrm{~g}$ for leaf, stem and root respectively compared to control plant values of $1.097 \pm 0.03,1.025 \pm$ 0.1 and $43.05 \pm 1.06 \mathrm{mg} / 100$ g respectively. Magnesium content of inoculated plants had mean reduction of $36.38 \pm 0.06,43.05 \pm 1.06$ and $45.52 \pm 0.06 \mathrm{mg} / 100 \mathrm{~g}$ for leaf, stem and root samples respectively as against control plant samples of $82.65 \pm 0.06,69.47 \pm 0.06$ and $61.39 \pm 0.53 \mathrm{mg} / 100 \mathrm{~g}$ respectively. Calcium and $\mathrm{P}$ were more in root samples than in leaf and stem samples of $A$. viridis. Percent- age reduction in $\mathrm{Ca}$ and $\mathrm{P}$ content by the virus in leaf, stem and root were $50.3 \%, 37.4 \%, 26.9 \%$ and $62.6 \%, 46.3 \%$, 35.9\% respectively.

Vitamins of $A$. viridis in leaf, stem and root were highly sensitive to TeMV infection depicted by severe decrease in content. In all plant samples analyzed, inoculated plants had lower amount of vitamins than the control. A trend of higher amounts of vitamins in leaf and stem than in root parts was observed except vitamins $\mathrm{B}_{1}$ and $\mathrm{E}$. Results analysis revealed that all vitamins were significantly $(P=0.05)$ decreased by the virus. Telfairia mosaic virus caused meaningful decrease in $\beta$-carotene with mean decrease in leaf, stem and root of $100.01 \pm 0.02,090.22 \pm 0.02$ and $087.63 \pm$ $0.12 \mu \mathrm{g} / \mathrm{dl}$ respectively. Control plant had corresponding decrease of $235.25 \pm 0.02,155.08 \pm 0.02$ and $105.41 \pm 0.01 \mu \mathrm{g} / \mathrm{dl}$. Folate had mean decrease of $51.39 \pm 0.01,45.17 \pm 0.02$ and $50.51 \pm 0.02 \mu \mathrm{g} /$ $\mathrm{dl}$ in leaf, stem and root respectively for inoculated $A$. viridis and $90.22 \pm 0.01,81.45 \pm 0.01$ and $72.86 \pm 0.01 \mu \mathrm{g} / \mathrm{dl}$ for control plants. Decrease in ascorbic acid were $2.45 \pm 0.33,1.90 \pm 0.13$ and 1.87 $\pm 0.33 \mathrm{mg} / 100$ compared to control values of $5.23 \pm 0.11,2.75 \pm$ 0.11 and $2.42 \pm 0.13 \mathrm{mg} / 100 \mathrm{~g}$ in leaf, stem and root respectively. Decreased in other vitamins are as presented in table 6 .

\section{Discussion}

Influence of TeMV disease was assessed on growth, yield and medicinal nutrients of $A$. viridis. Virus infected plants showed reduction in growth and yield in response to infection. Reduction in leaf area is disturbing because of the significance of leaf area in plant physiology. The smaller the leaf is, the smaller the leaf surface area for harvesting light energy with a resultant decrease in photosynthesis. The plant leaf is a key component in maintaining life on the planet earth through the food and oxygen production process of photosynthesis. Reduction in leaf area or size has a di- 
Influence of Telfairia mosaic virus on Growth, Yield and Phytonutrients of Amaranthus viridis L.

\begin{tabular}{|c|c|c|c|}
\hline Vitamins & Plant part & $\begin{array}{c}\text { Control } \\
\text { (mg/100 g) }\end{array}$ & $\begin{array}{l}\text { Inoculated } \\
\text { (mg/100 g) }\end{array}$ \\
\hline \multirow{3}{*}{ Potassium (K) } & Leaf & $47.25 \pm 0.06$ & $44.99 \pm 0.06$ \\
\hline & Stem & $28.19 \pm 0.53$ & $27.84 \pm 0.06$ \\
\hline & Root & $28.20 \pm 0.3$ & $26.87 \pm 0.26$ \\
\hline \multirow{3}{*}{ Sodium (Na) } & Leaf & $5.30 \pm 0.06$ & $3.66 \pm 0.26^{*}$ \\
\hline & Stem & $4.97 \pm 0.06$ & $3.13 \pm 0.3^{*}$ \\
\hline & Root & $5.64 \pm 0.06$ & $3.27 \pm 0.3^{*}$ \\
\hline \multirow{3}{*}{ Calcium (Ca) } & Leaf & $13.03 \pm 0.1$ & $8.67 \pm 0.06^{*}$ \\
\hline & Stem & $13.09 \pm 0.1$ & $8.20 \pm 0.06^{*}$ \\
\hline & Root & $12.99 \pm 0.1$ & $9.49 \pm 0.06^{*}$ \\
\hline \multirow{3}{*}{ Magnesium (Mg) } & Leaf & $82.65 \pm 0.06$ & $45.52 \pm 0.06^{*}$ \\
\hline & Stem & $69.47 \pm 0.06$ & $43.05 \pm 1.06^{*}$ \\
\hline & Root & $61.39 \pm 0.53$ & $36.38 \pm 0.06^{*}$ \\
\hline \multirow{3}{*}{ Iron $(\mathrm{Fe})$} & Leaf & $0.99 \pm 0.53$ & $0.51 \pm 0.13^{*}$ \\
\hline & Stem & $0.63 \pm 0.13$ & $0.40 \pm 0.06^{*}$ \\
\hline & Root & $0.54 \pm 0.53$ & $0.45 \pm 0.06^{*}$ \\
\hline \multirow{3}{*}{ Copper $(\mathrm{Cu})$} & Leaf & $1.097 \pm 0.03$ & $0.099 \pm 0.06^{*}$ \\
\hline & Stem & $1.025 \pm 0.1$ & $0.097 \pm 0.06^{*}$ \\
\hline & Root & $1.019 \pm 0.03$ & $0.095 \pm 0.0 .3^{*}$ \\
\hline \multirow{3}{*}{ Zinc (Zn) } & Leaf & $0.075 \pm 0.006$ & $0.045 \pm 0.006^{*}$ \\
\hline & Stem & $0.068 \pm 0.006$ & $0.050 \pm 0.006^{*}$ \\
\hline & Root & $0.040 \pm 0.006$ & $0.033 \pm 0.006^{*}$ \\
\hline \multirow{3}{*}{ Manganese (Mn) } & Leaf & $0.055 \pm 0.06$ & $0.053 \pm 0.2$ \\
\hline & Stem & $0.070 \pm 0.16$ & $0.066 \pm 0.3$ \\
\hline & Root & $0.064 \pm 0.16$ & $0.062 \pm 0.06$ \\
\hline \multirow{3}{*}{ Phosphorus (P) } & Leaf & $13.45 \pm 0.3$ & $5.03 \pm 1.7^{*}$ \\
\hline & Stem & $13.06 \pm 0.2$ & $7.01 \pm 0.3^{*}$ \\
\hline & Root & $11.26 \pm 0.2$ & $7.22 \pm 0.1^{*}$ \\
\hline
\end{tabular}

Table 5: Influence of Telfairia mosaic virus on mineral nutrients of Amaranthus viridis.

Means of three replicates $\pm \mathrm{SD}, \mathrm{P}=0.05,{ }^{*}=$ significant.

\begin{tabular}{|c|c|c|c|}
\hline Vitamins & Plant part & Control & Inoculated \\
\hline $\begin{array}{l}\text { Vitamin A } \\
(\beta \text {-carotene }) \\
\mu \mathrm{g} / \mathrm{dl}\end{array}$ & $\begin{array}{l}\text { Leaf } \\
\text { Stem } \\
\text { Root }\end{array}$ & $\begin{array}{l}235.25 \pm 0.02 \\
155.08 \pm 0.02 \\
105.41 \pm 0.01\end{array}$ & $\left\{\begin{array}{l}100.01 \pm 0.02 * \\
090.22 \pm 0.02 * \\
087.63 \pm 0.12 *\end{array}\right.$ \\
\hline $\begin{array}{l}\text { Vitamin } B_{1} \\
\text { (Thiamine) } \\
\text { mg/100 g }\end{array}$ & $\begin{array}{l}\text { Leaf } \\
\text { Stem } \\
\text { Root }\end{array}$ & $\begin{array}{l}0.129 \pm 0.03 \\
0.127 \pm 0.13 \\
0.118 \pm 0.03\end{array}$ & $\begin{array}{l}0.049 \pm 0.03^{*} \\
0.061 \pm 0.03^{*} \\
0.070 \pm 0.13^{*}\end{array}$ \\
\hline $\begin{array}{l}\text { Vitamin } \mathrm{B}_{2} \\
\text { (Riboflavin) } \\
\mathrm{mg} / 100 \mathrm{~g}\end{array}$ & $\begin{array}{l}\text { Leaf } \\
\text { Stem } \\
\text { Root }\end{array}$ & $\begin{array}{l}0.34 \pm 0.12 \\
0.27 \pm 0.1 \\
0.21 \pm 0.1\end{array}$ & $\begin{array}{c}0.21 \pm 0.02^{*} \\
0.19 \pm 0.1^{*} \\
0.14 \pm 0.1^{*}\end{array}$ \\
\hline $\begin{array}{l}\text { Vitamin } B_{3} \\
\text { (Niacin) } \\
\mathrm{mg} / 100 \mathrm{~g}\end{array}$ & $\begin{array}{l}\text { Leaf } \\
\text { Stem } \\
\text { Root }\end{array}$ & $\begin{array}{l}0.999 \pm 0.06 \\
0.908 \pm 0.06 \\
0.630 \pm 0.56\end{array}$ & $\begin{array}{l}0.534 \pm 0.06^{*} \\
0.561 \pm 0.06^{*} \\
0.477 \pm 0.06^{*}\end{array}$ \\
\hline $\begin{array}{l}\text { Vitamin } B_{5} \\
\text { (Pantothenic } \\
\text { acid) } \mathrm{mg} / 100 \mathrm{~g}\end{array}$ & $\begin{array}{l}\text { Leaf } \\
\text { Stem } \\
\text { Root }\end{array}$ & $\begin{array}{l}1.663 \pm 0.2 \\
1.512 \pm 0.2 \\
1.280 \pm 0.2\end{array}$ & $\begin{array}{l}0.901 \pm 0.1^{*} \\
1.020 \pm 0.1^{*} \\
0.917 \pm 0.2^{*}\end{array}$ \\
\hline $\begin{array}{l}\text { Vitamin } \mathrm{B}_{6} \\
\text { (Pyridoxine) } \\
\mathrm{mg} / 100 \mathrm{~g}\end{array}$ & $\begin{array}{l}\text { Leaf } \\
\text { Stem } \\
\text { Root }\end{array}$ & $\begin{array}{l}0.791 \pm 0.13 \\
0.583 \pm 0.33 \\
0.279 \pm 0.33\end{array}$ & $\begin{array}{l}0.312 \pm 0.03^{*} \\
0.302 \pm 0.03^{*} \\
0.186 \pm 0.33^{*}\end{array}$ \\
\hline $\begin{array}{l}\text { Vitamin } B_{9} \\
\text { (Folate) } \mu \mathrm{g} / \mathrm{dl}\end{array}$ & $\begin{array}{l}\text { Leaf } \\
\text { Stem } \\
\text { Root }\end{array}$ & $\begin{array}{l}90.22 \pm 0.01 \\
81.45 \pm 0.01 \\
72.86 \pm 0.01\end{array}$ & $\begin{array}{l}51.39 \pm 0.01^{*} \\
45.17 \pm 0.02^{*} \\
50.51 \pm 0.02^{*}\end{array}$ \\
\hline $\begin{array}{l}\text { Vitamin C } \\
\text { (Ascorbic acid) } \\
\text { mg/100 g }\end{array}$ & $\begin{array}{l}\text { Leaf } \\
\text { Stem } \\
\text { Root }\end{array}$ & $\begin{array}{l}5.23 \pm 0.11 \\
2.75 \pm 0.11 \\
2.42 \pm 0.13\end{array}$ & $\begin{array}{l}2.45 \pm 0.33^{*} \\
1.90 \pm 0.13^{*} \\
1.87 \pm 0.33^{*}\end{array}$ \\
\hline $\begin{array}{l}\text { Vitamin E } \\
(\alpha-\text {-Tocopherol) } \\
\mathrm{mg} / 100 \mathrm{~g}\end{array}$ & $\begin{array}{l}\text { Leaf } \\
\text { Stem } \\
\text { Root }\end{array}$ & $\begin{array}{l}1.40 \pm 0.06 \\
1.27 \pm 0.02 \\
1.25 \pm 0.03\end{array}$ & $\begin{array}{c}0.83 \pm 0.1^{*} \\
0.95 \pm 0.12^{*} \\
1.08 \pm 0.11^{*}\end{array}$ \\
\hline
\end{tabular}

Table 6: Influence of Telfairia mosaic virus infection on vitamins of Amaranthus viridis.

Means of three replicates $\pm \mathrm{SD}, \mathrm{P}=0.05,^{*}=$ significant. 
rect effect on leaf weight or mass and yield. Decrease in leaf area due to TeMV infection decreased light harvesting ability which determines growth and plant productivity. Decrease in Leaf area, number of primary shoot, number of leaves produced, fresh and dry leaf biomass which are yield indices significantly decreased yield with grave economic loses. Reduction implies low income generation by growers and decrease in medicinal efficiency of this A. viridis. Physiologically, plant leaf is a critical component in water transport system accounting for organic food and nutrient transport in the plant. Reduction in growth and yield due to TeMV stress in this study are similar to report of negative impact of TeMV infection on S. stenocarpa with reduction in growth and yield [16]. In tomato genotypes, Tomato mosaic virus caused reduction in plant height, fresh shoot weight, dry shoot weight, fresh root weight and dry root weight [17]. Virus infection triggers drastic changes in the overall plant efficiency. The differences in performance between TeMV inoculated and control plants may be the result of differences in the rate of assimilation per unit area of leaf surface, differences in respiration, or of the differences in the distribution of material to leaves. The larger the proportion of new material that the plant can utilize in leaf production the greater, it performance, if others factors are equal. The decrease in plant performance with prolonged infection may be attributed to decrease in size. Shoot height reduction orchestrated by TeMV infection resulted in stunting which is the most common symptoms observed in virus infected plants with remarkable effect on yield. Reduction in number of leaves produced by TeMV inoculated $A$. viridis plants was directly linked to shoot height reduction.

Telfairia mosaic virus infection decreased RGR, NAR and LAR of $A$. viridis. Similar reduction in RGR, NAR and LAR by Telfairia mosaic virus on Phaseolus vulgaris were reported by [18]. Net assimilation rate is the rate of increase in the dry weight of a plant per unit of active 'growing material'. It has relevance only during those phases of growth in which carbon assimilation accounts for the bulk of the change in dry weight of the plant. It is usual to express rates of carbon assimilation on a leaf-area basis, affirming that leaf area was an adequate measure of active 'growing material'. Decrease in NAR orchestrated by TeMV infection decreased growth due to low carbon production. Leaf area ratio is the ratio between total leaf area and total plant weight. [13] found that variation in LAR has more direct impact on whole-plant growth than NAR and the proportion of plant biomass invested in leaf area have an im- portant bearing on RGR. Leaf area is a driving variable for wholeplant growth. Variation in RGR, NAR and LAR which are important growth indicators is a cause for concern. Relative growth rate of a plant is the product of LAR which is leaf area per unit total plant biomass and NAR. Infected plants had inherently lower relative growth rates when compared to their control plant counterparts grown in the same experimental plots. The difference in RGR and consequently A. viridis performance was TeMV infection. Leaf area ratio is the product of specific leaf area, the ratio of leaf area and leaf weight, and the leaf weight ratio, which are indicators of the fraction of total plant weight allocated to the leaves.

Plants and plant parts have been used and are still being used traditionally in the treatment of diseases. Plants are the source of food and medicine to man. Various parts of the plant have been used to demonstrate the therapeutic properties of plants. The leaf, stem and root parts of $A$. viridis contain important phytonutrients that have health-protecting qualities thus used for the treatment of a wide range of diseases and to maintain good health. Phytonutrients help in the prevention of carcinogens formation, blocking the action of carcinogens on their targeted organs and tissues or suppression of cancer development on cells [18]. Nutrients like $\mathrm{Cu}, \mathrm{P}, \mathrm{Mg}, \mathrm{Ca}, \mathrm{Na}, \mathrm{Fe}, \mathrm{Zn}, \mathrm{K}, \mathrm{Mn}$ and vitamins required for normal metabolic activities were significantly reduced by TeMV. Findings of the present study coincide with report of reduction in $\mathrm{Na}, \mathrm{P}, \mathrm{Fe}$, $\mathrm{Zn}, \mathrm{Mg}, \mathrm{Cu}, \mathrm{K}$, vitamins and amino acids of Amaranthus hybridus by TeMV infection [19], Fe, Mg, Zn and P, vitamin A and C [20], thiamine, riboflavin and nicotinade in ecotypes of Telfairia occidentalis [21]. Each of these elements has different benefits. All of these minerals, even the trace ones are critical for proper body functioning. Adequate nutrition in human plays a critical role in building a strong immune system capable of protecting the body against infection. Poor nutrition emanating from food consumption with low nutrient levels exposes man to various diseases. People who consumed $A$. viridis infected with TeMV are bound to have low nutrients requirement since the virus caused significant reduction in essential nutrients importance in growth and development, and in maintaining the total well being of man. Decrease in these nutrients weakened human immune-defense and resistance to diseases.

Reduction in calcium by TeMV is disturbing because the human body needs more of Ca than any other mineral. The nutrient is used mainly to build strong bones and teeth, also by the blood, muscles 
and nerves. Calcium functions in heart contraction, muscle contraction, and in blood clotting, nerve conduction, cell membrane function, regulates blood pressure and enzyme activity vital to life. Calcium protects the colon cells from carcinogenic chemicals, prevents bone loss due to menopause and rheumatoid arthritis, reduce premenstrual symptoms. Decreased Ca content of $A$. viridis by TeMV infection decreases its therapeutic efficiency.

Reduction in $\mathrm{Cu}$ in this study agrees with previous report of decrease in $\mathrm{Cu}$ of $A$. hybridus by TeMV infection [19]. Copper plays an essential role in the conversion of iron to haemoglobin, provokes enzymes movement into the blood which binds with oxygen in the lungs, helps in the synthesis of proteins and enzymes and supports the proper functioning of the nervous system, stimulates the growth of red blood cells and thus needed for correct brain cells functioning. Copper is an integral part of certain enzymes of the digestive system and enable amino acid tyrosine to be usable, helping, it to work as a pigmenting factor for skin and hair. Copper aids in bones, tendons and connective tissues maintenance and development. It serves as a link with thyroid metabolism especially in the absorption and production of hormones. Reduction in $\mathrm{Cu}$ reduces its therapeutic potential.

Telfairia mosaic virus infection caused reduction in all vitamins studied. Vitamin $B_{1}$ is critical for carbohydrate metabolism and energy production, optimizes brain function and learning capacity, promotes mental alertness and memory, it fights depression, may slow atherosclerosis progression, needed for the formation of blood cell, a healthy nervous system, coordinates nerves and muscles interaction, reduced risk of cataracts, normal heart, stomach and intestine muscle tone. Reduction in thiamine orchestrated by TeMV infection led to its deficiency. Deficiency in thiamine causes beriberi; a disease manifested by pain or tingling sensation and weakness in the limbs, numbness in hands and legs, loss in weight, mood swing, irregular palpitation or enlarged heart, loss of appetite, breathing difficulty and congestion in the lung, gastrointestinal disorders such as indigestion and constipation, cancer sores, stunted growth, Crohn's disease, forgetfulness or mental confusion; severe deficiency can result in brain damage and Wernicke-korsakoff syndrome and edema. These conditions are unhealthy and should not be allowed to prevail hence the need to advance control of the virus.

Vitamin C was drastically reduced by TeMV. Decrease in vitamin $\mathrm{C}$ found in inoculated plants in this study is in line with report of decrease in vitamin C in Passiflora edulis infected with Telosma mosaic virus [22]. Normal levels of vitamin $C$ in the body play a key role is in the synthesis of collagen, helps the body immune system fight against infections and diseases, protects cells and tissues against damage, helps in cancer prevention, absorption of iron in the body, prevention of atherosclerosis and diseases of the heart, lowers high blood pressure, decreases susceptibility to allergens, expulsion of heavy metals and toxins from the body, used in the treatment of vaginitis, required for wounds healing, healthy skin, teeth and gum, and in the development of bones. Reduction in vitamin $\mathrm{C}$ due to TeMV infection leads to low level of vitamin $\mathrm{C}$ in $A$. viridis. People who consume infected $A$. viridis may suffer from conditions associated with low vitamin $\mathrm{C}$ such as scurvy, slow healing of bones and fractures, nose bleeding, gums bleeding, teeth decay and loose teeth, anemia, lethargy, loss of appetite, weight loss due to slower metabolism, painful joints or bones, irregular colds and infections, dry rough scaly skin, dry brittle hair, skin bruising and small spots of bleeding which appear as a pink spot.

Vitamin E is a powerful antioxidant that cancels the free radicals effect that cause tissue and cell damage, delays degenerative diseases, the risk of skin cancer, cataracts or age-related macular degeneration, protects skin from sun damage and ultraviolet radiation, help in the prevention of brain decline, Alzheimer's disease (neurological disease), lowers blood pressure and the body against heart disease and atherosclerosis. Vitamin $\mathrm{E}$ is also important in the formation of red blood cells, fertility and reproduction. Decrease the risk of prostrate and bladder cancer. It is an anti-aging vitamin, helps to boost the immune system functions in the body. Decrease in vitamin $\mathrm{E}$ occasioned by TeMV infection resulted in insufficient amount manifested by symptoms associated with low amount of vitamin E such as cataracts, weak immunity, anemia, loss of appetite, nausea, angina, muscles and limbs weakness, sometimes spasms, stiffness, numbness and tingling or burning sensation in arms, hand, legs and feet, jerkiness, clumsiness, problems of the digestive tract. The medicinal potentials of the other plant nutrients and their deficiencies have been extensively discussed [2]. Multiplication of virus particles in inoculated host cells was manifested by physiological changes in growth, yield, mineral nutrients and vitamins. Decrease in these medicinal nutrients by TeMV infection is a threat to health because people who consume infected $A$. viridis do not know that they are infected. This is worrisome in that they consume $A$. viridis low nutrients with its associated health problems hence the need for control. 


\section{Conclusion}

Influence of Telfairia mosaic virus on growth, yield and phytonutrients of Amaranthus viridis studied were severely decreased by Telfairia mosaic virus. Effect induced by TeMV was not obvious at two weeks after inoculation on all agromorphological parameters studied. Virus infection led to significant decrease in leaf area, shoot height, number of primary shoot branches, number of leaves, leaf fresh and dry weight, shoot fresh weight, root fresh weight, relative growth rate (RGR), net assimilation rate (NAR) and leaf area ratio (LAR). Effect of the virus on shoot dry weight and root dry weight was not significant. Copper, phosphorus, magnesium, calcium, iron, zinc and sodium were severely depleted by TeMV, effect on potassium and manganese was not significant. Thiamine, pyridoxine, $\beta$-carotene, ascorbic acid, niacin, pantothenic acid, folate, $\alpha$-tocopherol and riboflavin were severely decreased. Reduction in components studied necessitates control of Telfairia mosaic virus on Amaranthus viridis to maximize yield and therapeutic efficiencies.

\section{Acknowledgement}

Authors are grateful to the Department of Botany for providing the facilities needed to carry out this study.

\section{Conflict of Interest}

Authors declare that there is no conflict of interest.

\section{Bibliography}

1. Grubben G J H and Benton O A. "Plant resources of tropical Africa 2. Vegetables". PROTA Foundation, Wageningen (2004).

2. Mofunanya A. "Effect of simulated acid rain stress on the nutrient quality". Mauritius: Lambert Academic Publishing (2018).

3. Manandhar N P. "Plants and People of Nepal". Oregon: Timber Press (2002).

4. Chopra R N., et al. "Glossary of Indian Medicinal Plants (Including the Supplement)". Council of Scientific and Industrial Research. New Delhi: CSIR Publications (1986).

5. Quershi S J., et al. "A survey of useful medicinal plants of abbotabad, in Northern Pakistan". Trakia Journal of Science 6.4 (2008): 39-51.
6. Ferdous Md., et al. "Present biological status of potential medicinal plant of Amaranthus viridis: A comprehensive review". American Journal of Clinical and Experimental Medicine 3 (2015)3. 12-17.

7. Duke JA and Ayensu ES. Medicinal Plants of China. Algonac, Mich. Reference Publications, 1985 (OCoLC)570895850 (1985).

8. Kaur N., et al. "A novel antiproliferative and antifungal lectin from Amaranthus viridis Linn seeds". Protein Peptide Letter 13.9 (2006): 897-905.

9. Culver J N and Padmanabhan M S. "Virus-induced disease: altering host physiology one interaction at a time". Annual Review of Phytopathology 45 (2007): 221-243.

10. Shoyinka S A., et al. "The occurrence, properties and affinity of Telfairia mosaic virus (TeMV) potyvirus prevalent in Telfairia occidentalis in Telfairia (Cucurbitaceae) in South-western Nigeria”. Journal of Phytopathology 119 (1987): 13-17.

11. Mofunanya A A J., et al. "Changes in some enzymes activities of Amaranthus viridis L. inoculated with Telfairia mosaic virus (TeMV)". Journal of Applied Life Sciences International 15.3 (2017): 1-11.

12. Erlacher W A., et al. "Models for estimating leaf area of yacon". Horticultura Brasileira 34 (2016): 422-427.

13. Atwell B J., et al. "Plants in action: Adaptation in nature, performance in cultivation". South Yarra, Australia: MacMillian Company (1999).

14. Association of Official Analytical Chemists (AOAC). "Official Method of Analysis". 16th Edn., USA: Washington D. C. Press (1995).

15. Association of Official Analytical Chemists (AOAC). "Official Method of Analysis". 18th Edn., Association of Official Analytical Chemists, USA: Washington D. C. Press (2006).

16. Mofuanya A A J., et al. "Growth and yield assessment of Sphenostylis stenocarpa affected by virus infection". Iranian Journal of Plant Physiology 11.1 (2020): 3433-3441. 
17. Ullah N., et al. "Evaluation of tomato genotypes against tomato mosaic virus (ToMV) and its effect on yield contributing parameters". Pakistan Journal of Botany 49.4 (2017): 1585-1592.

18. Mofuanya A A J., et al. "Limitation on growth and yield of Phaseolus vulgaris L. due to Telfairia mosaic virus". Asian Plant Research Journal 7.2 (2021): 30-38.

19. Mofunanya A A J., et al. "Reaction of Amaranthus hybridus L. (Green) to Telfairia mosaic virus (TeMV) infection". International Journal of Virology 11.2 (2015): 87-95.

20. Mofunanya A A J., et al. "Effect of Telfairia mosaic virus (TeMV) infection on proximate, mineral and anti-nutritive contents of Telfairia occidentalis Hook (Fluted pumpkin)". Nigerian Journal of Botany 21.2 (2008): 304-315.

21. Mofunanya A A J., et al. "Determination of the effect of Telfairia mosaic virus on vitamins and amino acids profile of two ecotypes of Telfairia occidentalis (fluted pumpkin)". International Journal of Natural and Applied Sciences 4.1.2 (2009): 1-10.

22. Chen S., et al. "Identification of Telosma mosaic virus infection in Passiflora edulis and its impact on phytochemical contents". Virology Journal 15 (2018): 168.

\section{Assets from publication with us}

- Prompt Acknowledgement after receiving the article

- Thorough Double blinded peer review

- Rapid Publication

- Issue of Publication Certificate

- High visibility of your Published work

Website: www.actascientific.com/

Submit Article: www.actascientific.com/submission.php

Email us: editor@actascientific.com

Contact us: +919182824667 